\title{
Alkaliviscogram and Other Properties of Starch of Tropical Rice
}

\author{
Hiroshi SUZukI* and Bienvenido O. Juliano \\ Chemistry Department, The International Rice Research Institute, \\ Los Baños, Philippines \\ Received September 19, 1974
}

\begin{abstract}
In the alkaliviscogram of starch of 26 nonwaxy rices grown in the tropics, gelatinization normality correlated positively with final gelatinization temperature (BEPT) of starch $\left(r=0.969^{* *}\right)$ and negatively with alkali spreading value of milled rice $\left(r=-0.931^{* *}\right)$. Peak viscosity was not linearly related to amylose content. Among samples of rice starch having a high amylose $(>28 \%$ ) content, peak viscosity was correlated with the gel consistency of starch $\left(r=-0.690^{* *}\right)$ and of milled rice $\left(r=-0.644^{* *}\right)(n=18)$. These high-amylose starches showed the widest variation in peak viscosity. Amylose content, and gel consistency were inherited from the same parent in all nine varieties and lines studied, whereas peak viscosity, gelatinization normality and the final BEPT were inherited from either parent. The starch of five waxy rices showed higher peak viscosities even at a concentration of $1.8 \%$ as compared with a $2.0 \%$ nonwaxy rice starch.
\end{abstract}

Alkaliviscography is a method of characterizing starch by measuring the change in viscosity of a starch suspension as a function of the $\mathrm{KOH}$ concentration which is adjusted by successive addition of $5 \mathrm{~N} \mathrm{KOH} .^{1)}$ The method is complementary to Brabender amylography. ${ }^{2,3)}$ Japanese rice varieties which mature at similar temperatures have similar alkaliviscogram. ${ }^{2,3)}$ Differences in the ripening temperature during early and late season rice cultivation contributed more to the differences in the alkaliviscograms of Japanese rice ${ }^{4)}$ than did differences due to variety.

Tropical Asian rice varieties differ in starch properties more than do Japanese rice varieties, ${ }^{5 \sim 9)}$ and they have not been characterized systematically by alkaliviscography. In this paper, selected nonwaxy and waxy tropical rice samples were characterized for their alkaliviscogram and for other starch and milled rice properties including amylose content, gelatinization temperature and gel consistency.

\section{MATERIALS AND METHODS}

Samples. Rough rice samples were obtained from

* Permanent address: Department of Agricultural Chemistry, Faculty of Agriculture, Kagawa University, Miki-cho, Kagawa-ken, Japan. harvests at the International Rice Research Institute (IRRI) experimental farm from 1965 to 1973. One exception was BG11-11 which was from a 1971 crop in Peradeniya, Sri Lanka. Rough rice was dehulled by a Satake dehuller. Immature grains were removed from the brown rice before milling or starch preparation. Milling was done in $150 \sim 200 \mathrm{~g}$ of brown rice with a Satake TM-05 grain testing mill.

Starch was prepared from $20 \mathrm{~g}$ of brown or milled rice following the method of Reyes et al. ${ }^{51}$ The grains were soaked in water overnight at $4^{\circ} \mathrm{C}$, homogenized for $5 \mathrm{~min}$ in a Waring blendor at medium speed, and passed through a 180 -mesh sieve. The rice powder was extracted five times with $3 \%$ solution of TEMPO BF 404 (Philippine Refining Co., Inc., 40\% sodium dodecylbenzene sulfonate) containing $0.12 \% \mathrm{Na}_{2} \mathrm{SO}_{3}$ with at least $3 \mathrm{hr}$ of shaking with each extraction. The purified starch was then washed repeatedly with distilled water by suspending and centrifuging at $1000 \times g$ for $5 \mathrm{~min}$ and was finally air-dried at $25^{\circ} \sim 27^{\circ} \mathrm{C}$.

Properties of milled rice. Milled nonwaxy and waxy rice samples were analyzed for alkali spreading ${ }^{10 !}$ and for gel consistency. ${ }^{11 \prime} \quad$ For nonwaxy rice, $100 \mathrm{mg}$ milled rice ground in a Wig-L-Bug amalgamator was dispersed in $2 \mathrm{ml}$ of $0.2 \mathrm{~N} \mathrm{KOH}$. For waxy rice, $200 \mathrm{mg}$ milled rice ground in a Wig-L-Bug amalgamator was dispersed in $1 \mathrm{ml}$ of $0.3 \mathrm{~N} \mathrm{KOH}$ and neutralized with $1 \mathrm{ml}$ of $0.3 \mathrm{~N}$ acetic acid. Gel consistency was read in millimeters after the test tubes containing the gel had been standing for $1 \mathrm{hr}$ in a horizontal position. Amylograph peak viscosity was determined on $40 \mathrm{~g}$ of 40 -mesh waxy rice flour in $360 \mathrm{ml}$ water in a Brabender viscoamylograph 
with 700-cm.g sensitivity cartridge. Values were reproducible to within 50 Brabender units.

Alkaliviscography. A $2.0 \%$ starch suspension for nonwaxy starch samples was prepared by putting $2.5 \mathrm{~g}$ starch dry matter into a tall $400 \mathrm{ml}$ beaker containing $125 \mathrm{~g}$ distilled water including the moisture of the sample. A $1.8 \%$ starch suspension was used for waxy starch samples or $2.25 \mathrm{~g}$ starch dry matter in $125 \mathrm{~g}$ water. $\mathrm{KOH}(5.0 \pm 0.05 \mathrm{~N})$ solution was added to this suspension from a burette according to the method of Suzuki et al." After each $\mathrm{KOH}$ addition corresponding to a $0.01 \mathrm{~N}$ increase in $\mathrm{KOH}$ concentration every $5 \mathrm{~min}$, the suspension was stirred with a glass stirrer for $30 \mathrm{sec}$, and the viscosity of the starch suspension was measured at the fourth min by a Brookfield LV-type viscometer with No. 2 rotor at $60 \mathrm{rpm}$ ( 500 centipoise range). The viscometer reading was converted to centipoise (cps) by multiplying by a factor of $5 . \quad \mathrm{KOH}$ was added until $0.16 \mathrm{~N}$ above normality at peak or maximum viscosity was reached. Starting or gelatinization normality (gel. N) was that which coincided with the first viscosity reading above $22.5 \mathrm{cps}$. The difference in $\mathrm{KOH}$ normality from gel. $\mathrm{N}$ to peak viscosity was $J \mathrm{~N}$. The alkaliviscogram was obtained by plotting starch viscosity in centipoise against normality of $\mathrm{KOH}$.

Other properties of starch. The same starch samples were analyzed for amylose content by a simplified method, ${ }^{12)}$ residual protein by the method of Lowry et al. ${ }^{13 \prime}$ gel consistency (135 mg starch at $12 \%$ moisture/ $2 \mathrm{ml} 0.2 \mathrm{~N} \mathrm{KOH})^{11}$ and final gelatinization temperature (BEPT) by the photometric method using a Bausch and Lomb Spectronic 20 as described by Ignacio and Juliano. ${ }^{14)}$ The amylose and protein values were calculated on a dry weight basis. Gel consistency values of $135 \mathrm{mg} \mathrm{starch} / 2 \mathrm{ml} / 0.2 \mathrm{~N} \mathrm{KOH}$ was similar to gel consistency values of $100 \mathrm{mg}$ milled rice powder. Starch samples were also damaged by grinding $200 \mathrm{mg}$ starch for $30 \mathrm{sec}$ in a Wig-L-Bug amalgamator before assaying for gel consistency. Consistency values were read after $30 \mathrm{~min}$ instead of $1 \mathrm{hr}$. The temperature corresponding to an increase from the initial transmittance value of more than $5 \% \mathrm{~T}$ was considered the final BEPT. Duplicate runs of BEPT usually gave identical values but never differed by more than $1^{\circ} \mathrm{C}$.

\section{RESULTS AND DISCUSSION}

\section{Factors affecting alkaliviscogram of rice starch}

The effect of environmental and other factors on starch alkaliviscogram of a variety was investigated. Starch from the wet season crop tended to have a lower gel. $\mathrm{N}$ value than starch from the dry season crop of the same variety. Peak viscosity tended also to be higher in the dry season crop, and this was probably due in large part to the higher temperature (about $2^{\circ} \mathrm{C}$ ) during the dry season as compared with that occurring during the wet season at Los Baños. However, these differences were less than those due to variety and to the differences in alkaliviscogram of early and late season crops in Japan. ${ }^{2 \sim 4 \text { ) }}$

Most of the samples used for starch preparation were taken from mature grain; however, two varieties had inadequate sample of mature brown rice and thus immature grains were included in the starch preparation. Both immature and mature grains of Bluebonnet rice showed essentially the same starch alkaliviscogram curve. It appears that the alkaliviscogram characteristics of this rice variety are developed early during grain development as are other physical properties of the rice starch. ${ }^{15)}$ Gel. N was reproducible within $0.01 \mathrm{~N}$ whereas peak viscosity was reproducible within $10 \mathrm{cps}$ for each sample.

Log peak viscosity in the alkaliviscograms of the starch of IR8, IR5, and IR22 rice varieties showed a linear relationship with the log percent starch dry weight over the range of 1.2 to $2.9 \%$ starch as earlier reported for the Brabender amylogram peak viscosity by Anker and Geddes. ${ }^{16)}$ At the same $2 \%$ starch concentration, wet-milled flour of four nonwaxy samples sieved through 180-mesh screen, however, gave a peak viscosity lower by $19 \sim 28 \%$ when compared with the purified starch. Milled rice of two waxy samples gave a peak viscosity lower by $45 \sim 46 \%$ when compared to purified starch at the same $1.8 \%$ starch concentration. Microscopic examination of the wet-milled flour showed the presence of endosperm cell particles, indicating that the lower peak viscosity value of the flour was due to incomplete dispersion of the starch granules in comparison to purified starch. Rice proteinstarch interaction in alkaline gel is reported to be absent by Takeuchi et al. ${ }^{17}$

Varietal differences in alkaliviscogram of nonwaxy rice starch

The alkaliviscogram properties of the 26 
Table 1. Alkaliviscogram of Starch and Other Properties of Milled Rice and Starch of 26 Nonwaxy Rice Varieties and Lines

\begin{tabular}{|c|c|c|c|c|c|c|c|c|c|c|c|}
\hline \multirow[b]{3}{*}{ Variety or line } & \multirow[b]{3}{*}{$\begin{array}{l}\text { Crop } \\
\text { year }\end{array}$} & \multicolumn{2}{|c|}{ Milled rice } & \multicolumn{8}{|c|}{ Starch } \\
\hline & & \multirow[b]{2}{*}{$\begin{array}{l}\text { Alkali } \\
\text { spreading } \\
\text { value }\end{array}$} & \multirow{2}{*}{$\begin{array}{l}\text { Gel } \\
\text { consist- } \\
\text { ency } \\
(\mathrm{mm})\end{array}$} & \multicolumn{3}{|c|}{ Alkaliviscogram } & \multirow{2}{*}{$\begin{array}{l}\text { Peak } \\
\text { visc. } \\
\text { (cps) }\end{array}$} & \multirow{2}{*}{$\begin{array}{l}\text { Gel } \\
\text { con- } \\
\text { sist- } \\
\text { ency } \\
\text { (mim) }\end{array}$} & \multirow{2}{*}{$\begin{array}{l}\text { Final } \\
\text { BEPT } \\
\left({ }^{\circ} \mathrm{C}\right)\end{array}$} & \multirow[b]{2}{*}{$\begin{array}{c}\text { Amylose } \\
(\%)\end{array}$} & \multirow{2}{*}{$\begin{array}{c}\text { Residual } \\
\text { protein } \\
(\%)\end{array}$} \\
\hline & & & & $\begin{array}{c}\text { Gel. } \\
\mathrm{N}\end{array}$ & $\begin{array}{c}\text { Peak } \\
\mathrm{N}\end{array}$ & $J_{\mathrm{N}}$ & & & & & \\
\hline 1. Dee-geo-woo-gen & 1965 & 7.0 & 30 & 0.29 & 0.38 & 0.09 & 330 & 29 & 63 & 31.2 & 0.87 \\
\hline IR22 & 1971 & 7.0 & 30 & 0.30 & 0.40 & 0.10 & 312 & 30 & 64 & 30.4 & 0.58 \\
\hline \multicolumn{12}{|l|}{ Taichung } \\
\hline Native 1 & - & 7.0 & 30 & 0.30 & 0.40 & 0.10 & 295 & 30 & 65 & 32.2 & 0.98 \\
\hline IR 8 & 1972 & 7.0 & 30 & 0.31 & 0.39 & 0.08 & 386 & 29 & 62 & 28.8 & 0.73 \\
\hline \multicolumn{12}{|l|}{ Khao Dawk } \\
\hline Mali & - & 7.0 & 100 & 0.31 & 0.38 & 0.07 & 245 & 100 & 62 & 16.4 & 0.50 \\
\hline Nahng Mon S-4 & - & 7.0 & 78 & 0.31 & 0.39 & 0.08 & 192 & 79 & 63 & 28.2 & 0.49 \\
\hline \multicolumn{12}{|l|}{ Rikuto Norin } \\
\hline $21^{a}$ & 1973 & 6.5 & 64 & 0.32 & 0.40 & 0.08 & 214 & 100 & 63 & 14.0 & 0.58 \\
\hline IR480-5-9 & 1973 & 7.0 & 79 & 0.32 & 0.39 & 0.07 & 202 & 78 & 63 & 27.5 & 0.60 \\
\hline IR841-67-1 & 1969 & 6.0 & 90 & 0.35 & 0.41 & 0.06 & 218 & 100 & 65 & 18.5 & 0.35 \\
\hline Tainan $5^{a}$ & 1973 & 7.0 & 80 & 0.35 & 0.42 & 0.07 & 168 & 100 & 65 & 20.2 & 0.67 \\
\hline $\operatorname{IR} 24^{b 1}$ & 1973 & 7.0 & 46 & 0.35 & 0.40 & 0.05 & 175 & 100 & 64.5 & 18.7 & 0.10 \\
\hline Fujisaka $5^{a}$ & 1973 & 6.4 & 85 & 0.36 & 0.43 & 0.07 & 199 & 100 & 66 & 20.0 & 0.40 \\
\hline 2. Peta & 1968 & 5.0 & 31 & 0.40 & 0.45 & 0.05 & 238 & 37 & 71 & 30.8 & 0.79 \\
\hline TKM 6 & 1973 & 5.2 & 69 & 0.40 & 0.61 & 0.21 & 124 & 38 & 71 & 31.1 & 1.14 \\
\hline BG11-11 & 1971 & 5.5 & 84 & 0.41 & 0.59 & 0.18 & 110 & 78 & 71 & 30.6 & 0.86 \\
\hline IR5 & 1973 & 3.9 & 92 & 0.41 & 0.57 & 0.16 & 97.5 & 86 & 71 & 31.4 & 1.04 \\
\hline IR5 & 1973 & 4.2 & 81 & 0.41 & 0.53 & 0.12 & 93.5 & 74 & 71 & 32.6 & 0.86 \\
\hline IR262-43-8 & 1973 & 5.0 & 43 & 0.41 & 0.46 & 0.05 & 238 & 36 & 72 & 31.0 & 0.94 \\
\hline \multicolumn{12}{|l|}{ Tangkai } \\
\hline Rotan $^{c}$ & - & 5.2 & 50 & 0.41 & 0.45 & 0.04 & 205 & 58 & 72 & 30.4 & 0.74 \\
\hline Tadukan & 1972 & 5.0 & 35 & 0.41 & 0.60 & 0.19 & 125 & 46 & 71 & 29.0 & 0.74 \\
\hline $\mathrm{T} 136^{\circ}$ & - & 5.0 & 49 & 0.41 & 0.55 & 0.14 & 89 & 49 & 71 & 30.0 & 0.76 \\
\hline Sigadis & - & 5.0 & 89 & 0.42 & 0.47 & 0.05 & 261 & 55 & 72 & 30.4 & 0.75 \\
\hline Dular & 1973 & 4.2 & 84 & 0.43 & 0.60 & 0.17 & 90 & 95 & 73 & 31.6 & 0.71 \\
\hline Bluebonnet & - & 3.9 & 78 & 0.44 & 0.49 & 0.05 & 128 & 100 & 72 & 25.4 & 0.49 \\
\hline 3. IR841-5-3 & 1972 & 2.0 & 98 & 0.46 & 0.50 & 0.04 & 225 & 100 & 73.5 & 15.0 & 0.49 \\
\hline \multicolumn{12}{|l|}{ Century Patna } \\
\hline $231 /$ SLO 17 & 1972 & 2.0 & 84 & 0.46 & 0.51 & 0.05 & 191 & 100 & 74 & 21.4 & 0.51 \\
\hline IR127-2-2 & 1970 & 2.3 & 77 & 0.49 & 0.58 & 0.08 & 272 & 100 & 76 & 20.8 & 0.64 \\
\hline $\operatorname{LSD}(5 \%)$ & & 0.5 & 5 & & & & & 4 & 0.5 & 0.4 & 0.07 \\
\hline
\end{tabular}

a) Japonica or temperate variety.

b) Prepared by $O$. Diongco and excluded from correlation studies.

c) Inciudes immature grains.

nonwaxy samples (including three japonica varieties) grown at Los Baños differed widely (Table I). The gel. $\mathrm{N}$ values ranged from 0.29 to $0.49 \mathrm{~N}$. A comparison with other properties of milled rice and starch indicated good correlation of the gel. $\mathrm{N}$ values with the alkali spreading values of milled rice $(r=-0.931 * *)$ and final BEPT of $\operatorname{starch}(r=0.969 * *)$. The samples may be divided into three distinct groups based on gel. $\mathrm{N}$ into group 1:0.29 $0.36 \mathrm{~N}$; group $2: 0.40 \sim 0.43 \mathrm{~N}$; and group 3 : $0.46 \sim 0.49 \mathrm{~N}$ (Fig. 1). Starch in the gel. $\mathrm{N}$ group 1 had low final BEPT values and high alkali spreading values. The starch in group 2 had intermediate BEPT and alkali spreading values, whereas group 3 starches had the 


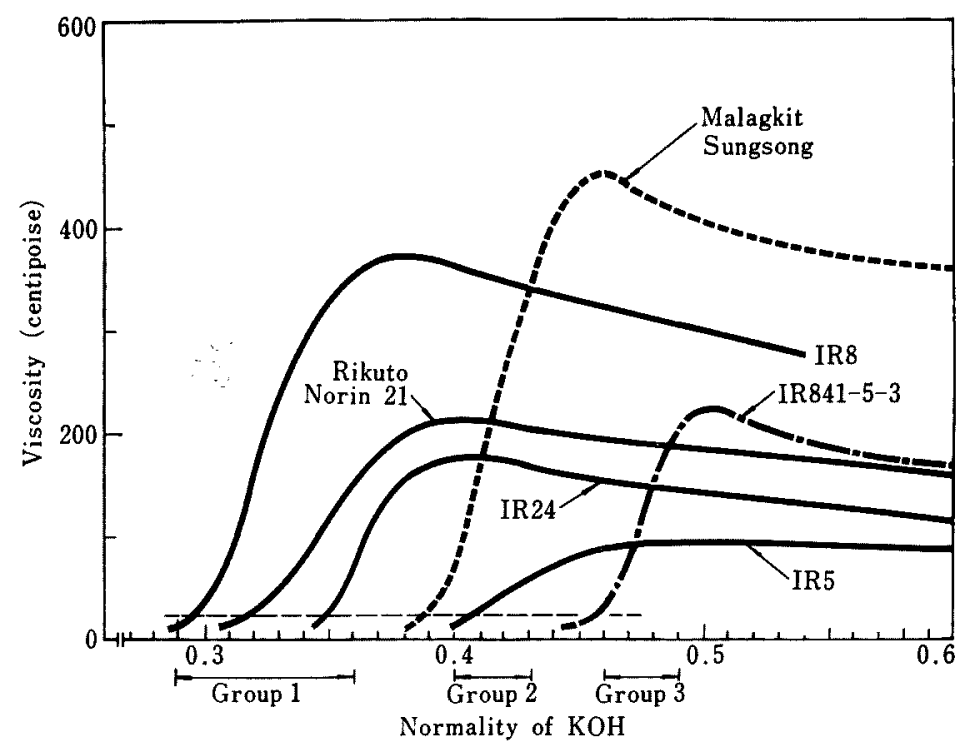

FIG. 1. Representative Alkaliviscograms of Rice Starch Differing in Gelatinization Normality Grouping and in Peak Viscosity.

All are $2 \%$ dry basis except Malagkit Sungsong which is $1.8 \%$.

highest BEPT values and were the most resistant to alkali digestion. The results indicate that like the alkali spreading value, gel. $\mathrm{N}$ is an index of final BEPT of rice starch.

The normality values at peak viscosity ranged from 0.38 to $0.61 \mathrm{~N}$ (Table $\mathrm{I}$ ), and these values followed the gel. $\mathrm{N}\left(r=0.784^{* *}\right)$, except that some samples in group 2 had higher peak $\mathrm{N}$ than the samples of group 3. KOH N corresponding to peak viscosity correlated positively with BEPT $(r=0.808 * \%)$ and negatively with alkali spreading value $\left(r=-0.683^{* *}\right)$. The normality range $(\Delta \mathrm{N})$ from gelatinization to peak viscosity extended from 0.04 to $0.21 \mathrm{~N}$. However, only six samples in group 2 showed $\Delta_{\mathrm{N}}$ of more than $0.10 \mathrm{~N}$. $\Delta \mathrm{N}$ was not related to gel. $\mathrm{N}\left(r=0.075^{\mathrm{ns}}\right)$ but was positively related to the amylose content $\left(r=0.464^{*}\right)$.

The peak viscosity in the alkaliviscogram (ranging from 89 to $386 \mathrm{cps}$ ) (Table I) was not correlated with the amylose content $(r=$ $\left.-0.147^{\mathrm{ns}}\right)$, and this may be attributed to the same wide range of peak viscosity of high amylose starches ( $89 \sim 386 \mathrm{cps}$ ), whereas lowamylose starches had intermediate values only. All six samples with $\Delta \mathrm{N}$ of more than $0.10 \mathrm{~N}$ had low peak viscosities, ranging between 89 and $125 \mathrm{cps}$, intermediate BEPT, and high amylose contents. A similar low and flat amylograph viscosity curve was obtained with the BG11-11 milled rice but not with IR5 milled rice. These samples showed similar mean granule size and slopes of their log peak viscosity-log percent concentration lines to those of the higher viscosity starches, such as IR8 and IR22. Differences in amylograph peak viscosity had also been reported for nonwaxy barley starches of similar amylose content. $^{18)}$

Peak viscosity correlated negatively with final BEPT $\left(r=-0.468^{*}\right)$, gel. $\mathrm{N}\left(r=-0.486^{*}\right)$, and gel consistency of milled rice $\left(r=-0.446^{*}\right)$, but not of starch $\left(r=-0.385^{\mathrm{ns}}\right)$. The correlation with BEPT may be due to the low BEPT of the four high amylose varieties with the highest viscosities of $295 \sim 386 \mathrm{cps}$. These varieties are semi-dwarf with similar dwarfing gene. The negative correlation of viscosity with gel consistency of milled rice was due in part to the hard gel consistency of these four varieties with high viscosity. When samples with low amylose content $(<25 \%)$ all with intermediate viscosity were excluded $(n=18)$, a better relationship of peak viscosity with gel consis- 
tency was obtained with milled rice. Hence, among high-amylose rices, gel consistency is a useful index for identifying samples with very high alkaliviscogram peak viscosity, which represent samples with hard gel consistency. ${ }^{11)}$

The residual protein tended to be higher in high amylose starch samples, in agreement with the report of Kongseree and Juliano.," However, amylose content was generally higher in starch than in milled rice due to removal of protein during starch preparation. There was no correlation between the final BEPT values and the amylose content, but the alkali spreading values correlated significantly with the final BEPT values in accordance with previous findings. ${ }^{5,93}$ However, no intermediate BEPT type low amylose rice was identified. In addition, samples with high BEPT were all low amylose and no high amylose rice with high BEPT was identified. ${ }^{19}$ ?

There was a high correlation between the gel consistency of milled rice and that of starch in $0.2 \mathrm{~N} \mathrm{KOH}\left(r=0.851^{* *}\right)$ indicating that starch may be the major fraction of milled rice which determines gel consistency. The amylose content was negatively correlated with gel consistency of starch and milled rice, since all low amylose samples had soft gel consistency values $(100 \mathrm{~mm})$ and hard values $(29 \sim 30 \mathrm{~mm})$ are confined to high-amylose rices.

A comparison of the starch properties in nine varieties and lines from Table I showed that the peak viscosity in the alkaliviscogram was obtained from either parent in seven rices, but was lower than those of the parents in IR5 and IR24 (Table II). The two backcrossed lines IR262-43-8 and IR480-5-9 inherited their viscosity from their female parent. Amylose content and gel consistency were inherited from the same parent, however. The final BEPT and gel. $\mathrm{N}$ characteristics, as well as viscosity, were inherited from the same parent in only six of the nine rices that were tested; IR24, IR127-2-2, and IR841-5-3 were the exceptions. These results agree with the lack of linear correlation between the amylose content, and BEPT and peak viscosity of rice starch.

\section{Alkaliviscogram of waxy rice starch}

A study of five waxy rices (1972 wet season crop) showed that the peak viscosities of $1.8 \%$ starch suspensions (Table III) were higher than those of nonwaxy rice starch run as a $2.0 \%$ suspension (Table I). Gel. $\mathrm{N}$ was slightly higher for waxy than for nonwaxy starch at similar final BEPT values. The observed difference in gel. $\mathrm{N}$ due to difference in the starch concentration ( 1.8 versus $2.0 \%$ ) ranged from $0 \sim 0.01 \mathrm{~N}$ only. $\Delta \mathrm{N}$ was narrow at $0.04 \sim 0.07 \mathrm{~N}$, which was also observed in Brabender amylography as short gelatiniza-

Table II. Parental Source of Alkaliviscogram Peak Viscosity, Amylose Content, Gel Consistency and BEPT or Gelatinization n of Starch in Nine Rice Varieties and Lines

\begin{tabular}{|c|c|c|c|c|c|}
\hline \multirow[b]{2}{*}{$\begin{array}{l}\text { Variety } \\
\text { or line }\end{array}$} & \multirow[b]{2}{*}{$\begin{array}{c}\text { Parents } \\
\text { (female/male) }\end{array}$} & \multicolumn{4}{|c|}{ Parental source ${ }^{a)}$ of } \\
\hline & & $\begin{array}{c}\text { Peak } \\
\text { viscosity }\end{array}$ & Amylose & $\begin{array}{c}\text { Gel } \\
\text { consist- } \\
\text { ency }\end{array}$ & $\begin{array}{c}\text { BEPT } \\
\text { or gel } N\end{array}$ \\
\hline IR5 & Peta/Tangkai Rotan & $<\mathrm{MF}$ & MF & M & MF \\
\hline IR 8 & Peta/Dee-geo-woo-gen & M & MF & M & $\mathrm{M}$ \\
\hline IR22 & IR8/Tadukan & F & $\mathrm{F}$ & $\mathrm{F}$ & $\mathrm{F}$ \\
\hline IR24 & IR8/IR127-2-2 & $<\mathrm{MF}$ & $\mathrm{M}$ & $\mathbf{M}$ & $\mathrm{F}$ \\
\hline IR 127-2-2 & CP 231/SLO 17//Sigadis & M & $\mathrm{F}$ & $\mathrm{F}$ & $>\mathrm{MF}$ \\
\hline IR262-43-8 & Peta $^{3} /$ Taichung Native 1 & $\mathrm{~F}$ & $\mathrm{~F}$ & $\mathrm{~F}$ & F \\
\hline IR480-5-9 & Nahng Mon S $-4^{2} /$ Taichung Native 1 & $\mathrm{~F}$ & $\mathrm{~F}$ & $F$ & MF \\
\hline IR 841-5-3 & IR262-43-8/Khao Dawk Mali & MF & M & $\mathrm{M}$ & $>\mathrm{MF}$ \\
\hline IR $841-67-1$ & IR262-43-8/Khao Dawk Mali & MF & $\mathbf{M}$ & M & $\mathrm{M}<\mathrm{F}$ \\
\hline
\end{tabular}

a) $\mathrm{F}=$ female parent; $\mathrm{M}=$ male parent; $\mathrm{MF}=$ similar to both parents; $>\mathrm{MF}=$ higher than both parents; $<\mathrm{MF}=$ lower than both parents; $\mathrm{M}<\mathrm{F}=$ closer to male parent than to female parent. 
Table III. Alkaliviscogram of Starch and Other Properties of Milled Rice and Starch of Five WaXy Rice Samples (1972 wet season crop)

\begin{tabular}{|c|c|c|c|c|c|c|c|c|c|c|}
\hline \multirow{3}{*}{$\begin{array}{l}\text { Variety } \\
\text { or line }\end{array}$} & \multicolumn{3}{|c|}{ Milled rice } & \multicolumn{7}{|c|}{ Starch } \\
\hline & \multirow{2}{*}{$\begin{array}{l}\text { Alkali } \\
\text { spreading } \\
\text { value }\end{array}$} & \multirow{2}{*}{$\begin{array}{l}\text { Gel } \\
\text { consist- } \\
\text { ency } \\
(\mathrm{mm})\end{array}$} & \multirow[b]{2}{*}{$\begin{array}{l}\text { Amylograph } \\
\text { peak visc. } \\
\text { (BU) }\end{array}$} & \multicolumn{4}{|c|}{ Alkaliviscogram } & \multirow{2}{*}{$\begin{array}{c}\text { Gel } \\
\text { consist- } \\
\text { ency } \\
(\mathrm{mm})\end{array}$} & \multirow[b]{2}{*}{$\begin{array}{c}\text { Final } \\
\text { BEPT } \\
\left({ }^{\circ} \mathrm{C}\right)\end{array}$} & \multirow[b]{2}{*}{$\begin{array}{c}\text { Residual } \\
\text { protein } \\
(\%)\end{array}$} \\
\hline & & & & $\underset{N}{\text { Gel. }}$ & $\begin{array}{c}\text { Peak } \\
\text { N }\end{array}$ & $\Delta \mathrm{N}$ & $\begin{array}{l}\text { Peak } \\
\text { visc. } \\
\text { (cps) }\end{array}$ & & & \\
\hline \multicolumn{11}{|l|}{ Malagkit } \\
\hline Sungsong & 6.0 & 68 & 200 & 0.39 & 0.46 & 0.07 & 452 & 100 & 61 & 0.38 \\
\hline IR 833-6-2 & 5.0 & 54 & 480 & 0.39 & 0.44 & 0.05 & 540 & 100 & 65 & 0.37 \\
\hline IR833-34-1 & 5.0 & 56 & 325 & 0.39 & 0.45 & 0.06 & 441 & 100 & 67 & 0.40 \\
\hline IR253-16-1 & 5.0 & 45 & 375 & 0.40 & 0.46 & 0.06 & 435 & 100 & 70 & 0.35 \\
\hline Panpet 63 & 2.3 & 28 & 555 & 0.49 & 0.55 & 0.06 & 528 & 100 & 77 & 0.36 \\
\hline $\operatorname{LSD}(5 \%)$ & 0.3 & 6 & & & & & & NS & 3 & NS \\
\hline
\end{tabular}

tion times from initial increase in viscosity to peak viscosity. Peak viscosity in alkaliviscogram tended to be higher in samples with high amylograph peak viscosity (Table III), but the peak occurs at lower temperature in the amylogram of waxy rice than in nonwaxy rice but they occur at similar $\mathrm{N}$ in the alkaliviscogram.

This study on some of the physical properties of milled rice and starch of nonwaxy and waxy tropical rice indicated that tests performed on milled rice can provide reliable indexes of these physical properties of rice starch. The alkali spreading value can be used to measure the final BEPT of starch in a rice breeding program. Gel consistency of milled rice does estimate the gel consistency of rice starch satisfactorily. Because starch is the main constituent of milled rice, the amylose content of milled rice can serve as an index of the amylose content of rice starch.

Although Brabender amylography of milled rice and starch and alkali viscography of rice starch provide additional data on starch physical properties, they require a considerable amount of an operator's time per sample. Also the amylograph requires a large sample $(40 \mathrm{~g})$. Thus these types of analyses are not suitable for routine use in a rice breeding program. Alkali test, gel consistency, and amylose content determinations, which are presently used in the IRRI rice breeding program, have been found to be suitable indicators of the viscosity properties of rice starch.
Advanced promising lines may have to be rechecked with Brabender amylography and alkaliviscography.

Acknowledgements. The senior author thanks the Ministry of Education of Japan for his sabbatical leave. T. T. Chang and B. S. Vergara provided the rice samples and A. A. Perdon, O. Diongco and J. Beato provided analytical assistance.

\section{REFERENCES}

1) H. Suzuki and N. Taketomi, Kogyo Kagaku Zasshi 59, 45 (1956).

2) H. Suzuki, S. Chikubu and T. Tani, Nippon Nôgeikagaku Kaishi, 33, 275 (1959).

3) H. Suzuki, S. Hizukuri and Z. Nikuni, ibid., 37, 63 (1963).

4) H. Suzuki and N. Murayama, Int. Rice Comm. Newslett. (sp. issue), 82 (1967).

5) A. C. Reyes, E. L. Albano, V. P. Briones and B. O. Juliano, J. Agr. Food Chem., 13, 438 (1965).

6) S. Chikubu, Int. Rice Comm. Newslett. (sp. issue), 146 (1967).

7) B. O. Juliano, ibid., (sp. issue), 93 (1967).

8) B. O. Juliano, M. B. Nazareno and N. B. Ramos, J. Agr. Food Chem., 17, 1364 (1969).

9) N. Kongseree and B. O. Juliano, ibid., 20, 714 (1972).

10) R. R. Little, G. B. Hilder and E. H. Dawson, Cereal Chem., 35, 111 (1958).

11) G. B. Cagampang, C. M. Perez and B. O. Juliano, J. Sci. Food Agr., 24, 1589 (1973).

12) B. O. Juliano, Cereal Sci. Today, 16, 334 (1971).

13) O. H. Lowry, N. J. Rosebrough, A. L. Farr and R. S. Randall, J. Biol. Chem., 193, 265 (1951).

14) C. C. Ignacio and B. O. Juliano, J. Agr. Food Chem., 16, 125 (1968). 
15) V. P. Briones, L. G. Magbanua and B. O. Juliano Cereal Chem., 45, 351 (1968).

16) C. A. Anker and W. F. Geddes, ibid., 21, 335 (1944).

17) I. Takeuchi, K. Shimada and S. Nakamura,
Nippon Nôgeikagaku Kaishi, 41, 260 (1967).

18) B. W. DeHaas and K. J. Goering, Stärke, 24, 145 (1972).

19) H. M. Beachell, Int. Rice Comm. Newslett. (sp. issue), 161 (1967). 